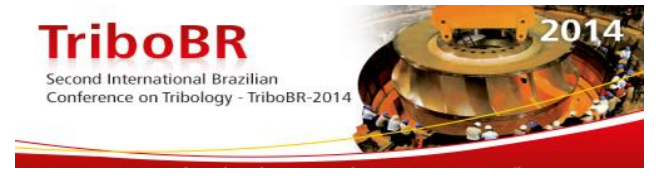

\title{
TRIBOLOGICAL BEHAVIOR OF THREAD COMPOUND FOR APPLICATIONS IN OIL AND GAS INDUSTRY*
}

\author{
Nicolás Ariel Zabala ${ }^{1}$ \\ Walter Roberto Tuckart ${ }^{2}$ \\ Pablo Adrián Castro ${ }^{3}$
}

\begin{abstract}
During the make-up and break-out of the connections, threaded joints are exposed to intense mechanical and tribological solicitations. The connection performance is influenced by its geometry, material properties, surface treatments and thread compound. The aim of this work is to evaluate and characterize the tribological behavior of different thread compounds applied on manganese phosphated carbon steel under low speed and high pressure sliding contact. Four thread compounds were evaluated: one containing lead, zinc and graphite; other lead-free, containing copper and finally, the last two lead-free and containing non-metallic solids. The tribological behavior was analyzed by a block-on-ring tribotest. During the test, load varied linearly between $250 \mathrm{~N}$ and $7000 \mathrm{~N}$; loading and unloading lasted $14 \mathrm{sec}$ and were performed in opposite directions of rotation to simulate the make-up and breakout operations. Friction force and load as a function of time were registered. Upon completion of the test, wear surfaces were analyzed by SEM, optical microscopy and energy dispersive spectroscopy. The obtained results show that the lead and zinc containing thread compound displayed the best behavior, showing a wear reduction of approximately $20 \%$. These results are in line with previously known oilfield experience. Average COF values around 0.15 were measured and no significant differences between dopes were observed; indicating that the wear behavior was influenced by the additive package.
\end{abstract}

Keywords: Thread compound; Friction; OCTG connections; Sliding wear.

1 Eng., Doctoral Student, Engineering Department, UNS, CONICET, Bahía Blanca, Bs. As., Argentina.

2 Dr., Professor and Researcher, Engineering Department, UNS, CONICET, Bahía Blanca, Bs. As., Argentina.

3 Dr., Head, Surface Chemistry \& Coatings Department, TenarisSiderca R\&D Center (REDE-AR), Campana, Bs. As., Argentina.

* Technical contribution to the $2^{\text {nd }}$ International Brazilian Conference on Tribology - TriboBR 2014, November $3^{\text {rd }}$ to $5^{\text {th }}$, 2014, Foz do Iguaçu, PR, Brazil. 


\section{INTRODUCTION}

Reducing material wear rates the oil and gas industry to improve equipment life and reliability would significantly improve productivity.

In recent years, environmental concerns have brought about the need to improve the tribological performance and reliability of oil and gas casing and tubing strings.

During connections assembly, threaded joints are exposed to intense mechanical and tribological solicitations. There are many important design factors that affect the performance of an OCTG (Oil Country Tubular Good) connection, such as tensile strength, galling resistance, and leak resistance [1-3]; moreover it is also influenced, among others, by surface treatments and thread compound.

Manganese phosphate is an industrial coating that combined with proper lubricants is commonly used to reduce friction and improve lubrication in sliding components. Manganese phosphate coatings are created by chemical conversion, and the main component of the film is named hureaulite, $(\mathrm{Mn}, \mathrm{Fe})_{5} \mathrm{H}_{2}(\mathrm{PO} 4)_{2}$. It is claimed in the literature that these coatings have excellent lubricity and anti-scuffing properties [4-6].

Different thread compounds or dopes (in the oil \& gas jargon) are used in the oil fields. The most common of them, based on API RP $5 A 3$ standard, contain heavy metals such as copper, lead and zinc in their composition thus restricting their application in some regions, due to environmental hazards. Therefore, the need for replacing them by other dopes containing graphite, PTFE and other non-metallic solids is becoming increasingly important [7-10].

The main purpose of this work was to evaluate the tribological behavior of different thread compounds used in the oil and gas industry. For this purpose, dopes were applied on manganese phosphated carbon steel samples that were analyzed under low and high pressure sliding contact. The wear and friction behavior was assessed by a block-on-ring tribotest. This device was modified from the block-on-ring Timken method test according to ASTM D2509 [11]. In order to discuss the role of the additives during the tribological process, the distribution of additives was observed by scanning electron microscopy (SEM) with an energy dispersive spectroscopy (EDS) detector.

In this study, it has been experimentally demonstrated using ANOVA analysis that, the lead, zinc and copper containing thread compound evidenced the best behavior. Also, it was observed that the wear behavior is not influenced by the friction capability of the lubricant, being the wear dependent on the additives package.

\section{MATERIAL AND METHODS}

\subsection{Tribotest}

A schematic representation of the tribometer used to analyze the tribological behavior is shown in Figure 1. A lubricated block-on-ring Timken method test according to ASTM D 2509 [11] was modified for the purpose of reproducing the contact geometry and sliding conditions existing in the seal of premium OCTG connections. In this geometric configuration, the block is in contact with the ring from the bottom, allowing the lubricant to be confined between the contact surfaces.

\footnotetext{
* Technical contribution to the $2^{\text {nd }}$ International Brazilian Conference on Tribology - TriboBR 2014, November $3^{\text {rd }}$ to $5^{\text {th }}$, 2014, Foz do Iguaçu, PR, Brazil.
} 


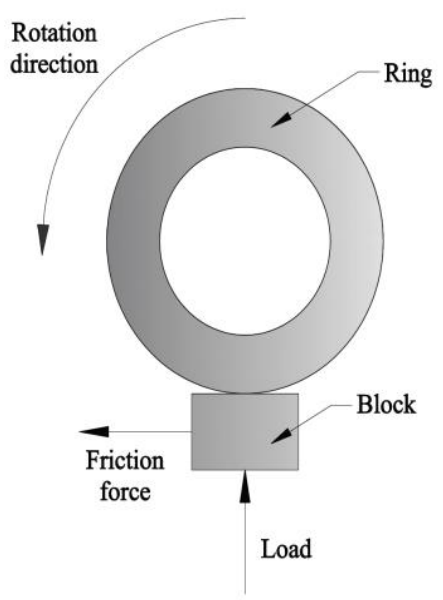

Figure 1. Schematic representation of the block-on-ring configuration used in wear tests.

\subsection{Test Samples}

Figure 2 shows the geometric design and dimensions of the samples. The rings were of AISI/SAE 1045 steel and the blocks of AISI/SAE 4140 steel. Blocks are prismatic square base of $12.32 \pm 0.10 \mathrm{~mm}$ wide and $19.05 \pm 0.41 \mathrm{~mm}$ long according to ASTM D 2509 [11]. Also, the blocks were coated with manganese phosphate following the standard procedure used for couplings in the industry. Rings were machined with a diameter of $49.22+0.025,-0.127 \mathrm{~mm}$ and a width of $7 \pm 0.05 \mathrm{~mm}$ (Figure 2). The rings roughness varied between Ra values of 1.81 and $2.17 \mu \mathrm{m}$, range in which the wear effect of the roughness variation is minimized. Table 1 shows the chemical analysis of the materials which was performed by optical emission spectrometry.

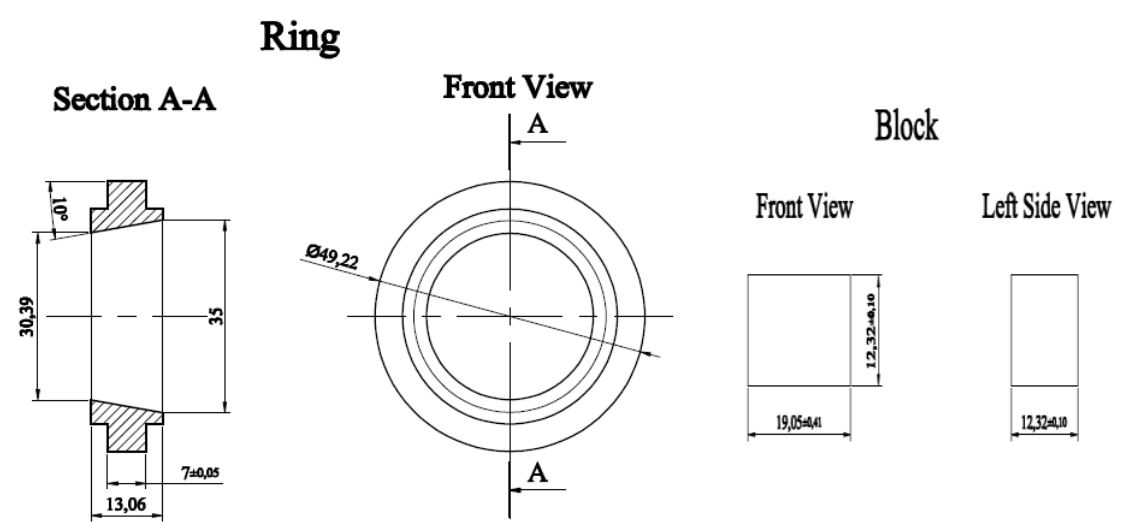

Figure 2. Test specimens design and geometry.

Table 1. Chemical analysis of specimen materials (wt.\%)

\begin{tabular}{lcccccccc}
\hline Component & $\mathrm{C}$ & $\mathrm{Mn}$ & $\mathrm{Ni}$ & $\mathrm{Si}$ & $\mathrm{Mo}$ & $\mathrm{Cr}$ & $\mathrm{P}$ & $\mathrm{S}$ \\
\hline Ring & .461 & .69 & .039 & .306 & .0026 & .037 & .015 & .0072 \\
\hline Block & .441 & .905 & .0315 & .308 & .172 & .975 & .018 & .0019 \\
\hline
\end{tabular}

Before phosphating, the blocks were polished with a 500 grit, leaving the surface with a $R_{a}$ roughness of $0.10 \mu \mathrm{m}$. Then, the samples were degreased by immersion in a weak alkaline solution $(60 \mathrm{~g} / \mathrm{l})$ at $83^{\circ} \mathrm{C}$ for $15 \mathrm{~min}$ and rinsed in water. The activation step was performed by immersion in a commercial activator solution (manganese

* Technical contribution to the $2^{\text {nd }}$ International Brazilian Conference on Tribology - TriboBR 2014, November $3^{\text {rd }}$ to $5^{\text {th }}$, 2014, Foz do Iguaçu, PR, Brazil. 
phosphate colloidal suspension) at $40 \stackrel{\circ}{\mathrm{C}}$ for 1 minute under agitation. The activated specimens were then immersed in a commercial phosphating solution composed of phosphoric acid, manganese phosphate and accelerators at $99^{\circ} \mathrm{C}$ for 10 minutes. After rinsing with water, the phosphated samples were dried with hot air blow.

\subsection{Characterization of Lubricants and Additives Identification}

The dopes evaluated in this study are commercially available lubricants for premium quality pipe threaded joints used in the oil and gas industry.

The four different thread compounds evaluated are listed and designated with a single letter in Table 2. In addition, this table includes a brief identification and characterization of each dope. Oilfield experience and full-scale tests indicate that the "A" grease has the best tribological performance. To assure a homogeneous mixture, the lubricants were stirred before the beginning of each test.

Table 2. Thread compounds used in the experiments

\begin{tabular}{cc}
\hline Thread Compound Identification & Additives \\
\hline "A" (simil API Modified) & containing lead, zinc and graphite \\
\hline "B" & lead-free, containing copper \\
\hline "C" & lead-free, containing non-metallic solids \\
\hline "D" &
\end{tabular}

To establish the amount of additives in the dopes, the extraction technique with Soxhlet equipment was used. The extraction was performed with toluene, separating the solids from the lubricating fluid, which was retained by the solvent. Then the amount of solids was calculated by difference of weight.

The additives evaluation and distribution was performed by microscopic observation, analytical techniques and scanning electron microscopy (SEM) with an energy dispersive spectroscopy (EDS) detector. SEM observation required drying the dope samples to avoid fumes being released into the microscope chamber. Also, the EDS mapping technique was used to provide a meaningful picture of the element distribution.

NLGI consistency was measured using the test defined by standard ASTM D217 "cone penetration of lubricating grease".

\subsection{Test Procedure}

Before testing, the surface roughness of the ring was measured with a surface roughness profilometer (Hommel Tester T500). During each test, four complete cycles (charge-discharge), i.e. 8 strokes, were conducted. Loading and unloading were carried out in opposite directions of rotation, providing a way of simulating the make-up and break-out of the connections. Both charge and discharge lasted 14 seconds, time in which they reached a sliding distance of $409 \mathrm{~mm}$. This was achieved with 2.65 revolutions of the ring, rotating at 11.35 RPM and reaching in this way a sliding rate of $29.26 \mathrm{~mm} / \mathrm{sec}$.

During charging, load was varied linearly from $250 \mathrm{~N}$ to $7000 \mathrm{~N} \mathrm{MPa}$ and was alternated at the discharge. The friction force and load were measured using load cells and recorded as a function of time by a data acquisition system. The coefficient of friction was calculated by dividing the friction force by the applied normal load.

A method for applying lubricant was also developed, in which, at the beginning of each cycle, $52.8 \mathrm{~mm}^{3}$ of dope was uniformly placed on the ring contact surface. This

\footnotetext{
* Technical contribution to the $2^{\text {nd }}$ International Brazilian Conference on Tribology - TriboBR 2014, November $3^{\text {rd }}$ to $5^{\text {th }}$, 2014, Foz do Iguaçu, PR, Brazil.
} 
was done for simulate the actual make-up conditions of a real connection. Given the volume of dope to be put and the specific gravity of each one, the exact weight amount was determined. Then, this amount of lubricant was measured using a scale with a $0.0001 \mathrm{~g}$ accuracy.

Upon completion of the test, worn specimen surfaces were examined using optical microscopy and scanning electron microscopy. Furthermore, wear was assessed by measuring the volume of the material removed from the block using optical microscopy and a specific software according to ASTM G 77 standard [12]. The worn volume was measured on three different spots for each test, and each one was based on 5 width measurements.

Then, knowing the geometry of the contact surfaces (Figure 3), the block scar volume was calculated with the following equation (Equation 1):

ScarVolume $\left[\mathrm{mm}^{3}\right]=\frac{D^{2} t}{8}\left[2 \sin ^{-1} \frac{b}{D}-\sin \left(2 \sin ^{-1} \frac{b}{D}\right)\right](1)$

Where "t" is the scar length (ring width) in $\mathrm{mm}$, "D" the ring diameter (mm) and "b" the average scar width $(\mathrm{mm})$.

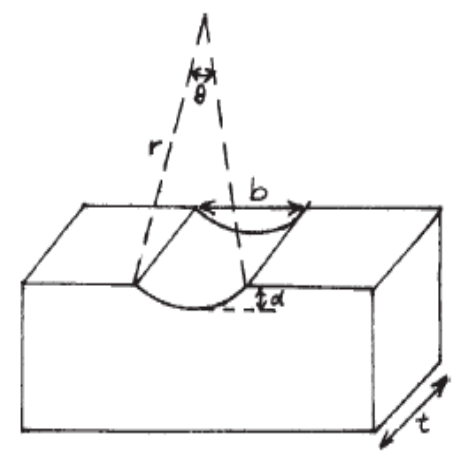

Figure 3. Schematic representation of the block scar volume.

According to ASTM G 77 [12], block scar volume is not calculated from block mass loss because block mass is subject to effects of materials transfer, generation of oxide films, or lubricant penetration in the material.

\subsection{Statistical Considerations}

Four or five replicate tests were conducted for each set of test conditions in order to get an average wear and friction behavior. A new test specimen pair was used for each replicate test.

The experimental design of the tests was selected on the basis of a statistical analysis of the results. The worn results were evaluated by analysis of variance (ANOVA) and least significant difference (LSD) techniques.

With the purpose of taking unbiased estimates of the treatments mean values, the treatments (dopes) were randomly applied to the experimental units (samples).

ANOVA can decompose the variation between all the tests, into the variation due to lubricants and the corresponding variation between the specimens of each treatment. Moreover, due to the difficulty of producing the same surface roughness in all the rings, and in order to minimize the effect of varying the ring roughness; the rings were selected and assigned to each trial with a completely randomized design. In

* Technical contribution to the $2^{\text {nd }}$ International Brazilian Conference on Tribology - TriboBR 2014, November $3^{\text {rd }}$ to $5^{\text {th }}$, 2014, Foz do Iguaçu, PR, Brazil. 
addition, the rings available for testing were selected from a larger group of rings, choosing those with a roughness value of Ra near $2 \mu \mathrm{m}$. It has been found that in the range of roughness between $1.8 \mu \mathrm{m}$ and $2.2 \mu \mathrm{m}$ of $\mathrm{Ra}$, the effect of roughness variability on wear is minimized.

\section{RESULTS AND DISCUSSION}

\subsection{Characterization of Lubricants and Additives Identification}

Solid lubricants are effectively used in antiseizure compounds and threading compounds, providing sealing and a friction reduction effect for threaded pipe assembly [13]. Applications involving low sliding speeds and high contact loads also benefit from solid additives.

The results of the lubricants characterization and additives identification for the four dopes evaluated in this study is presented in Table 3.

Table 3. Results of lubricant characterization and additives identification

\begin{tabular}{|c|c|c|c|c|}
\hline & "A" & "B" & "C" & "D" \\
\hline Color & Black & Black & Beige & Black \\
\hline Appearance & bright & bright & bright & bright \\
\hline Consistency (NLGI) & № 1 & № 1 & № 1 & № 1 \\
\hline Thickener & lithium & lithium & lithium & lithium \\
\hline Solids & $64 \%$ & $53 \%$ & $51 \%$ & $43 \%$ \\
\hline Lead powder & $30.5 \%$ & & & \\
\hline Zinc dust & $12.2 \%$ & & & \\
\hline Lime + talc & & $20 \%$ & $31 \%$ & \\
\hline Teflon (PTFE) & & $5 \%$ & $20 \%$ & \\
\hline Copper & & $3 \%$ & & \\
\hline Amorphous Graphite & $18 \%$ & $25 \%$ & & \\
\hline $\begin{array}{l}\text { Amorphous and } \\
\text { Crystalline Graphite }\end{array}$ & & & & $30 \%$ \\
\hline Mica & & & & $13 \%$ \\
\hline Fluid viscosity & ISO VG 100 & ISO VG 100 & $<$ ISO VG 100 & ISO VG 100 \\
\hline
\end{tabular}

The analysis with EDS and EDS mapping of the "A" and " $B$ " thread compounds was performed. However, the mapping of the "C" and " $D$ " dopes was not done due to the impossibility of drying them properly. Table 4 presents the colors designated for each element.

Table 4. Designation of colors for each additive element observed by EDS mapping

\begin{tabular}{cccccc}
\hline $\mathrm{Pb}$ & $\mathrm{Zn}$ & $\mathrm{Cu}$ & $\mathrm{C}$ & $\mathrm{Ca}$ & $\mathrm{Si}+\mathrm{Mg}$ \\
\hline pink & purple & light blue & red & yellow & green \\
\hline
\end{tabular}

Energy dispersive spectroscopy (EDS) confirmed the presence of heavy metals such as lead and zinc in dope "A", while EDS mapping was used to determine the metallic particles morphology and distribution. The presence of carbon, calcium, silicon, and magnesium was also verified. The latter elements could correspond to magnesium silicate (talc). Calcium indicates the presence of lime and carbon is found as graphite in the dope.

In Figure 4a, a SEM image of dried " $A$ " thread compound is shown. For better understanding, the mapping images corresponding to the different elements were

* Technical contribution to the $2^{\text {nd }}$ International Brazilian Conference on Tribology - TriboBR 2014, November $3^{\text {rd }}$ to $5^{\text {th }}$, 2014, Foz do Iguaçu, PR, Brazil. 


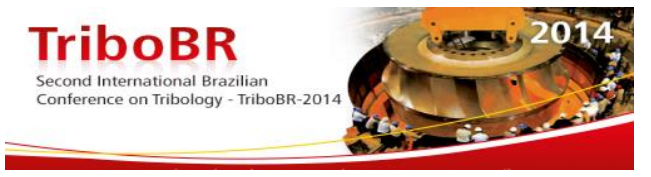

overlapped with the original SEM image and illustrated in Figure 4b. This combining of EDS maps from different elements allowed highlighting different phases in the analyzed area such as, for example, magnesium silicate (talc).

The analysis of "B" thread compound identified the presence of copper, carbon, calcium, silicon and magnesium. In this dope the copper is added as copper flakes and the other elements are present in the same way as in dope "A". Figure 5a shows a SEM image corresponding to dope "B". The overlap of the mapping images on the original SEM image is shown in Figure $5 b$.

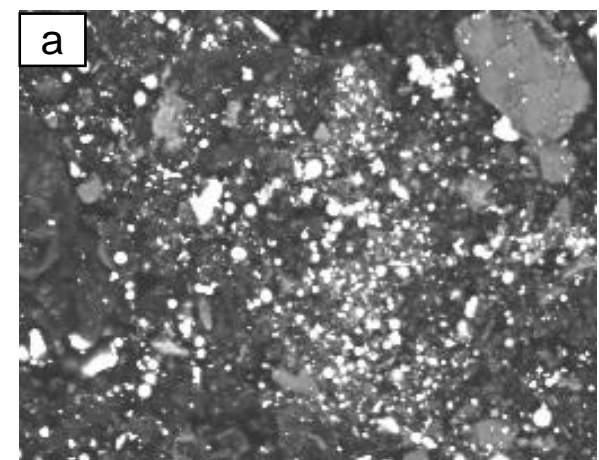

Figure 4. (a) SEM image at 400x for dope "A". with the original image.

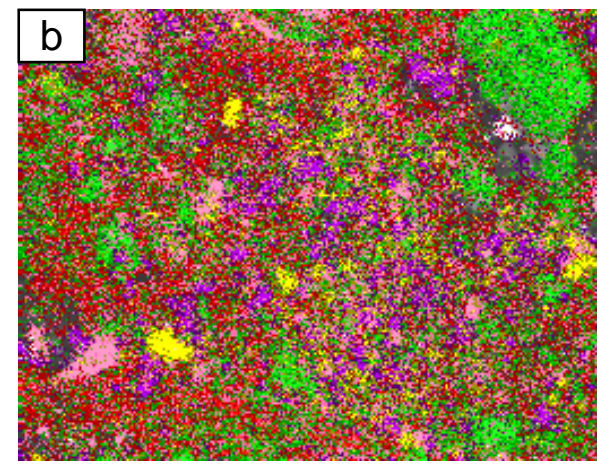
(b) Additive maps of $\mathrm{Al}, \mathrm{Cu}, \mathrm{Zn}, \mathrm{Pb}$ and $\mathrm{C}$ overlaped

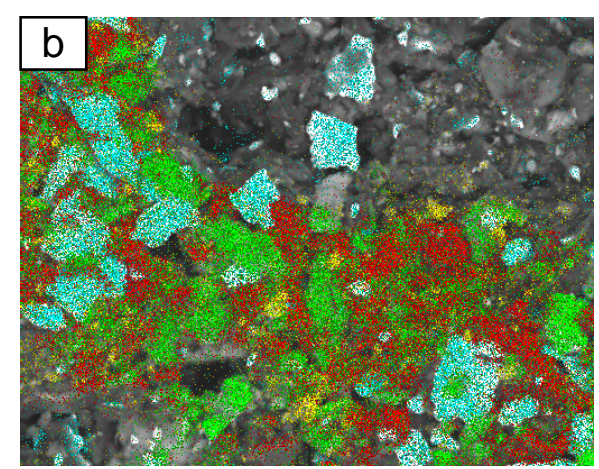

Figure 5. (a) SEM image at 400x for the thread compound "B". (b) Additive maps of $\mathrm{Al}, \mathrm{Cu}, \mathrm{Zn}, \mathrm{Pb}$ and C overlapped with the original image.

It has been known that metals such as zinc, copper, lead, antimony, bismuth, and molybdenum possess desirable lubricating characteristics including antiwear and antioxidant properties. Lead and zinc were extensively used early in the industry's history as antiwear and EP additives, but environmental concerns have led to their virtual disappearance. These metals are the best known and most widely used antiwear additives not only in thread compounds but also in engine oils, transmission fluids, and hydraulic oils [7].

Graphite and polytetrafluoroethylene (PTFE or teflon) possess excellent friction reduction properties and indirectly contribute some antiwear/EP characteristics. The PTFE lubrication properties are at least partially the result of its high softening point, having one of the smallest coefficients of friction among solid lubricants. Teflon (PTFE), similarly to lead, has the ability to form a protective surface film. In addition, the use of PTFE for bushings and bearings due to its self-lubricating properties is well known.

Graphite, a popular solid lubricant, also acts mainly as an inert filler for joint sealing purposes and provides some lubricity. Its lamellar structure makes this pigment an

* Technical contribution to the $2^{\text {nd }}$ International Brazilian Conference on Tribology - TriboBR 2014, November $3^{\text {rd }}$ to $5^{\text {th }}$, 2014, Foz do Iguaçu, PR, Brazil. 
effective load-bearing lubricant additive. Although the amorphous graphite used in compound "B" is not a lubrication grade, it would provide some lubricity. Lubrication functionality decreases as crystallinity and graphitization decrease. For occasions where only minor lubricity is needed and perhaps a more thermally insulating coating is required, amorphous graphite would be chosen. Combining amorphous and crystalline graphite can also be used to tune the amount of lubrication to suit the requirements of the application [7].

\subsection{Wear Behavior}

A special design block-on-ring test was used to analyze the wear behavior of the different dopes being evaluated. The high contact pressure, low sliding speed and marginal lubrication involved in the tribosystem set the conditions for an adhesive wear mechanism.

From the counterpart block worn volume measuring, the corresponding mean values of wear were calculated for each evaluated dope and the standard error of the means was weighted considering ANOVA analysis. This analysis gives an accurate estimation of the standard error because it contemplates the number of tests carried out in the estimation of the mean and determined the error considering the total set of tests.

In Figure 6 the wear results are shown in a bar graph, considering the worn volume as the ponderable value and the type of lubricant as the classification variable. Also the graph includes the results of the Fisher LSD comparison test, wherein the treatment with a common letter were not significantly different from the wear point of view.

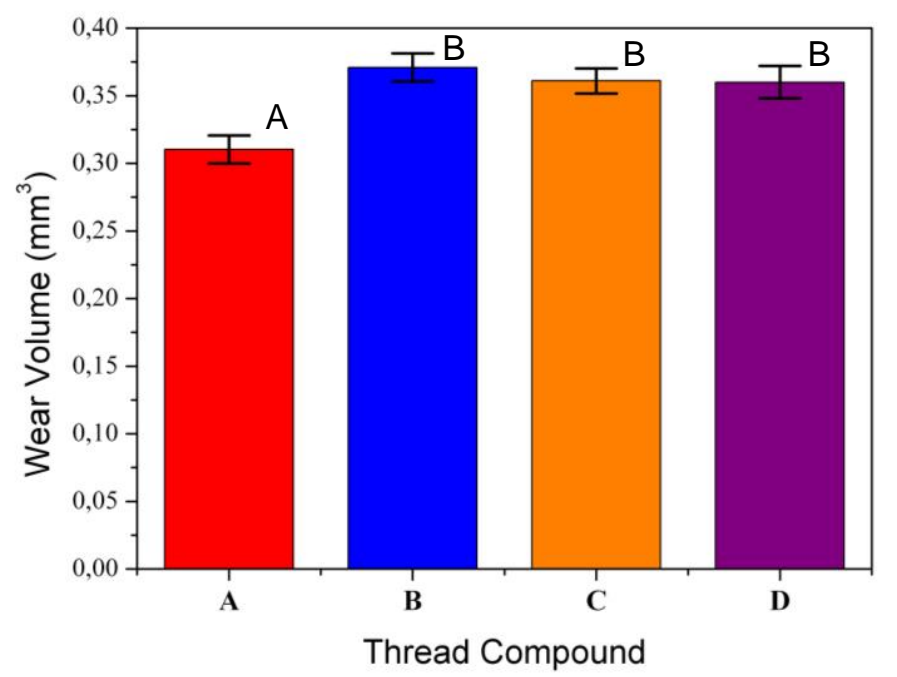

Figure 6: Graphic of wear volume as a function of the type of lubricant.

The wear results were analyzed with ANOVA indicating, with an error less than $1 \%$, that there were highly significant differences in the wear behavior produced by changing the lubricant.

Moreover, the Fisher's protected LSD test was applied to identify the differences. The result of the two-tailed Fisher LSD test, even with a significance level of $1 \%$, indicated that there were highly significant differences between applying the grease "A" with respect to the others; i.e. the thread compound designated as "A" had the

* Technical contribution to the $2^{\text {nd }}$ International Brazilian Conference on Tribology - TriboBR 2014, November $3^{\text {rd }}$ to $5^{\text {th }}$, 2014, Foz do Iguaçu, PR, Brazil. 
best wear performance. This dope evidenced a wear reduction of about 15 to $20 \%$ in comparison with the others lubricants.

The " $A$ " dope had an excellent wear performance because the lead and zinc additives of this dope were compacted between the contact surfaces, preventing metal-metal contact [14]. Figure 7 shows a SEM image and an energy-dispersive Xray (EDS) spectroscopy demonstrating the presence of lead and zinc on the wear scar. Additionally, Carper et al. [8] in a study developed with a rotating pin-on-box test with similar contact conditions of those of the real pipe connections, reported that the lead powder additive is capable of forming a surface film of lower shear strength than the base metal.

Furthermore, no evidence was found to ensure that there were differences in the wear behavior between the "B", "C" and "D" dopes. To establish differences between "B", "C" and "D" dopes, more replicate test should be done to improve the comparisons.

Regarding the comparison between "B", "C" and "D" lubricants, it was worth noting that the copper flakes present in dope "B" added nothing to the wear resistance compared to the metal-free " $C$ " and " $D$ " thread compounds.
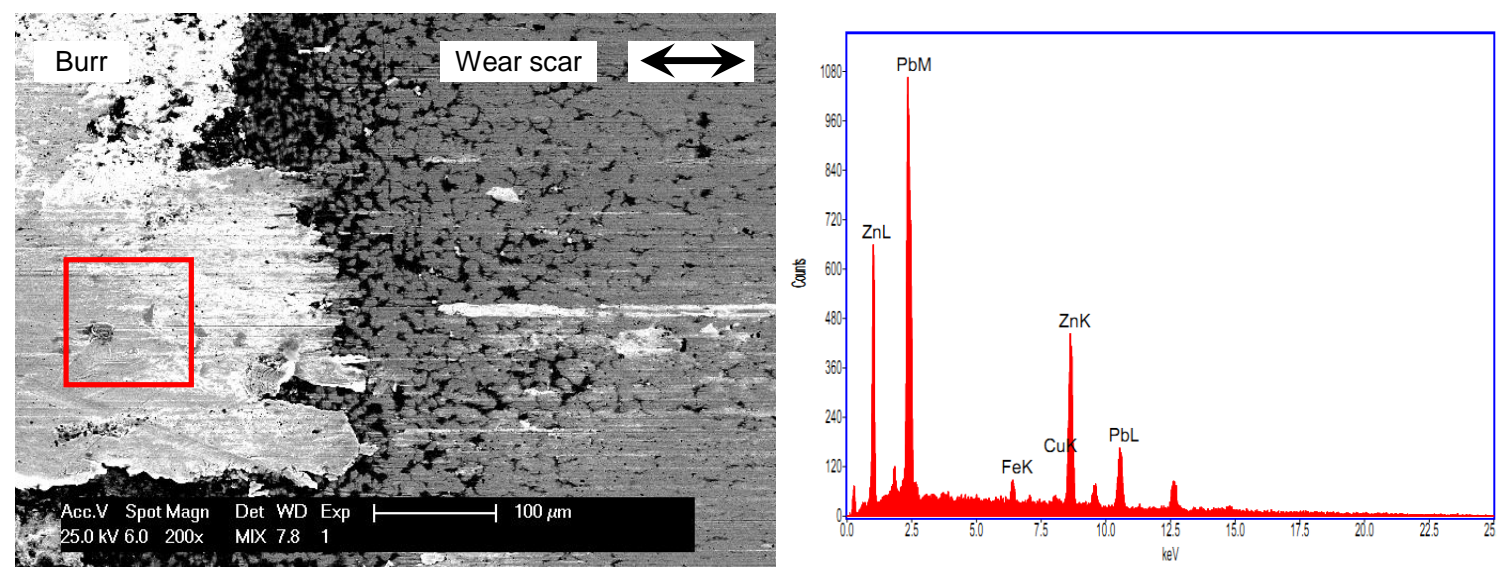

Figure 7. Left: SEM image at 200x of the wear scar of a block specimen after a test evaluated with dope "A". Right: EDS spectroscopy of the select area in the SEM image. Peaks corresponding to zinc, lead, iron, and cooper can be observed.

\subsection{Friction Behavior}

On the whole, the friction coefficient values from the block-on-ring tests present similar patterns for all compounds evaluated. This is consistent with a study already developed by Carper et al. [9] with pin-on-box tests where little difference in friction performance between API Modified thread compound and a nonmetal-containing compound is shown.

In Figure 8 (left) a typical set of results for a charge stroke of a block-on-ring test is presented. As can be seen from the graph, the normal load, friction force and coefficient of friction are all plotted as a function of the time.

As illustrated by Figure 8 left both the normal load and the friction force increase monotonically as the test proceeds. Whereas the friction coefficient typically varies in a non-monotonic fashion, increasing to a maximum and then decreasing up to an steady value as the load is increased. This behavior is typical of boundary lubrication regime. Although the friction evolution is similar to that obtained by Carper et al. [14] in rotating pin-on-box tests lubricated with API Modified thread compound, the friction coefficient results obtained in this study are slightly higher than those reported by

* Technical contribution to the $2^{\text {nd }}$ International Brazilian Conference on Tribology - TriboBR 2014, November $3^{\text {rd }}$ to $5^{\text {th }}$, 2014, Foz do Iguaçu, PR, Brazil. 
Carper et al. Furthermore, the values of the coefficient of friction are in line with those published by Stewart et al. [15] for the range of contact pressure evaluated in the current tests.

Also, from the graph in Figure 8 (left) it can be seen that a marked decrease in the COF value with the completion of the ring revolutions is noted after $5.2 \mathrm{~s}$ and $10.4 \mathrm{~s}$. This is in line with the running-in phenomenon where the friction decreases when the surface asperities become burnished.

Moreover, the burnishing effect is also shown by the decreases of the COF results from the first charge stroke to the last charge stroke. The largest COF difference was seen between the first cycle and the second, where the COF was reduced by approximately 15\% (Figure 8 right). This reduction is in accordance with the study developed by Stewart et al. [15] where a COF reduction of the $20 \%$ between the first cycle and the second was reported.
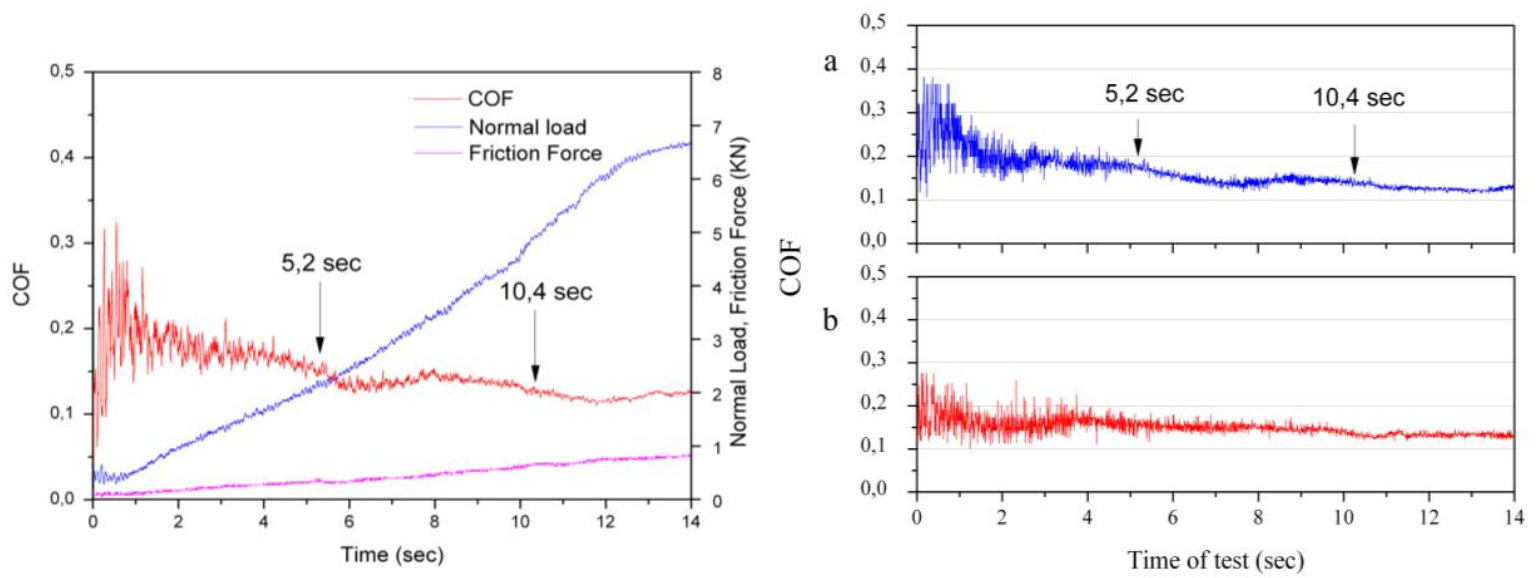

Figure 8. Left: Graphic of behavior of normal load, friction force and friction coefficient with time during a test. Right: Graphic of COF comparison between charge strokes for a test developed with dope "C": (a) first charge stroke; (b) second charge stroke.

It would be expected that when the load is increased, the area through which the asperities interact is increasing as the test proceeds. For unlubricated conditions a constant coefficient of friction is expected in accordance with Amonton's law of friction [16]. However, when the contact is lubricated, the COF may not remain constant. As a result, in the region where the COF is constant a tendency to dry friction was observed. This was due to the squeezing out of the lubricant as the load was increased. Moreover, in the case of dope "A", when the lubricant was squeezed the lead and zinc particles were compacted, avoiding the metal-metal contact. The same behavior was confirmed by Carper et al. [14] in a study conducted to determine friction coefficient behavior in OCTG connections.

In Figure 9 the mean of the average COF in the initial charge cycle is plotted against the type of thread compound used. No significant difference can be identified from comparing the average COF values obtained for each dope. Therefore, the wear behavior was dependent of the additive package and not influenced by the friction capability of the lubricant.

\footnotetext{
* Technical contribution to the $2^{\text {nd }}$ International Brazilian Conference on Tribology - TriboBR 2014, November $3^{\text {rd }}$ to $5^{\text {th }}, 2014$, Foz do Iguaçu, PR, Brazil.
} 
4 Hivart P, Hauw B, Bricout JP, Oudin J. Seizure behaviour of manganese phosphate coatings according to the process conditions. Tribology International. 1997;30(8):561570.

5 Hivart P, Hauw B, Dubar L, Bricout JP. Numerical identification of bulk behavior law of manganese phosphate coatings. Comparison with tribological properties. Journal of Coatings Technology. 2003;75(942):37-44.

6 Oyamada $\mathrm{T}$, Inoue $\mathrm{Y}$. Evaluation of the wear process of cast iron coated with manganese phosphate. Tribology Transactions. 2003;46(1):95-100.

7 Lubricant additives: Chemistry and Applications. 2nd ed. Wilmington: Rudnick Leslie R.; 2009

8 Carper HJ, Ertas A, Cuvalci O. Rating Thread Compounds for Galling Resistance. Journal of Tribology. 1995;117:639-645.

9 Carper HJ, Ertas A, Cuvalci O. Effect of contact geometry and other tribological variables on the friction coefficient in threaded connections. In: American Society of Mechanical Engineers, Petroleum Division. Proceedings of the Energy-Sources Technology Conference; 1994 Jan 23-26; New Orleans, LA, USA. ASME; 1994.p. 117-122.

10 Leech A, Roberts A. Development of dope-free premium connections for casing and tubing. SPE Drilling and Completion 2007;22(2):106-111.

11 ASTM standard D2509, 2003 (2008), Standard Test Method for Measurement of LoadCarrying Capacity of Lubricating Grease (Timken Method), ASTM International, West Conshohocken, PA, 2008, DOI: 10.1520/D2509-03R08, www.astm.org.

12 ASTM standard G77, 2005 (2010), Standard Test Method for Ranking Resistance of Materials to Sliding Wear Using Block-on-Ring Wear Test, ASTM International, West Conshohocken, PA, 2010, DOI: 10.1520/G0077-05R10, www.astm.org.

13 Jacobs NL. Tubes and pipes used in oil and gas production industry. Patent US5180509; 1993 Jan 19.

14 Carper HJ, Ertas A, Issa J, Cuvalci O. Effect of some material, manufacturing, and operating variables on the friction coefficient in OCTG connections. Journal of Tribology. 1992;114:698-705.

15 Stewart F, Le HR, Williams JA, Leech A, Bezensek B, Roberts A. Characterisation of friction and lubrication regimes in premium tubular connections. Tribology International. 2012;53:159-166.

16 Archard JF, "Wear Theory and Mechanisms," ASME Wear Control Handbook, eds., Peterson MB and Winer WO. 1980; pp. 35-88.

* Technical contribution to the $2^{\text {nd }}$ International Brazilian Conference on Tribology - TriboBR 2014, November $3^{\text {rd }}$ to $5^{\text {th }}, 2014$, Foz do Iguaçu, PR, Brazil. 